\title{
AVALIAÇÃO COM IMAGENS EM OFICINAS DE CINEMA PARA CRIANÇAS: ELABORAÇÃO E APLICAÇÃO
}

\author{
Andrea Vicente Toledo Abreu ${ }^{1}$ \\ Elise Helene Moutinho Bernardo de Moraes ${ }^{2}$
}

\begin{abstract}
RESUMO: Este artigo apresenta análise de uma metodologia de avaliação com o uso de imagens com crianças. Procurou-se sistematizar as ações e procedimentos para que possam ser adaptadas, aprimoradas e contribuírem com avaliação de diferentes aprendizagens. Tal método foi elaborado pelo Grupo de Pesquisa Educação e Mídia (PUC-Rio) e testado em oficinas de cinema, realizadas com alunos do quarto e quinto ano do Ensino Fundamental, em uma escola de Cataguases-MG. Vega (2015) e Migliorin et al. (2016) contribuíram na criação e aplicação das oficinas, e a avaliação das aprendizagens foi construída em diálogo com os Estudos da Infância. Realizou-se rodas de conversa conduzidas com o uso de cartões com desenhos e símbolos, registradas em vídeos, fotografias e anotações. A análise mostrou que estratégias como sentar-se ao chão, debater sobre o que está representado em imagens e falar espontaneamente, podem suscitar falas importantes das crianças e evidenciar aprendizagens de natureza diversa.
\end{abstract}

Palavras-chave: Metodologia da Avaliação. Educação pelo Cinema. Rodas de Conversa. Aprendizagem. Infância.

\section{MAGE EVALUATION IN CINEMA WORKSHOPS FOR CHILDREN: PREPARATION AND APPLICATION}

ABSTRACT: This paper presents an analysis of an evaluation methodology using images with children. The aim was to systematize the actions and procedures so that they can be adapted, improved and contribute to the assessment of different

\footnotetext{
${ }^{1}$ Doutora em Ciências Humanas-Educação pela Pontifícia Universidade Católica do Rio de Janeiro, com período sanduíche no Programa de Pós-Graduação Memória: Linguagem e Sociedade pela Universidade Estadual do Sudoeste da Bahia. Integrante do GRUPEM - Grupo de Pesquisa Educação e Mídia (PUC-Rio). Professora e pesquisadora na Universidade do Estado de Minas Gerais/UEMG. Cataguases - MG/Brasil. E-mail: andreatoledo4@gmail.com

${ }^{2}$ Doutoranda em Ciências Humanas-Educação pela Pontifícia Universidade Católica do Rio de Janeiro, com período sanduíche como bolsista do Programa Capes Print, no Doutoramento em Estudos da Criança da Universidade do Minho, Braga - Portugal. Integrante do GRUPEM - Grupo de Pesquisa Educação e Mídia (PUC-Rio). E-mail: elisedemoraes@gmail.com
} 
learning. This method was developed by the Grupo de Pesquisa Educação e Mídia (PUC-Rio) and tested in cinema workshops, held with students from the fourth and fifth years of elementary school, in a school in Cataguases-MG. Vega (2015) and Migliorin et al. (2016) contributed to the creation and application of the workshops and the evaluation of learning was woven in dialogue with Childhood Studies. The dialogue circles were realized using cards with drawings and symbols, recorded in videos, photographs and notes. The analysis showed that strategies such as sitting on the floor, debating what is represented in images and speaking spontaneously, can reveal important speeches from children and show learning of a different nature.

Keywords: Evaluation Methodology. Education by the cinema. Dialogue circle. Learning. Childhood.

\section{EVALUACIÓN COM IMÁGENES EN TALLERES DE CINE PARA NIÑOS: ELABORACIÓN E APLICACIÓN}

RESUMEN: Este artículo presenta un análisis de una metodología de evaluación utilizando imágenes con niños. Buscamos sistematizar las acciones y procedimientos para que se pueda adaptarse, mejorar y contribuir a la evaluación de diferentes aprendizajes. Este método fue desarrollado por el Grupo de Pesquisa Educação e Mídia (PUC-Río) y probado en talleres de cine, realizados con estudiantes de cuarto y quinto año de primaria, en una escuela en CataguasesMG. Vega (2015) y Migliorin et al. (2016) contribuyeron a la creación y aplicación de los talleres. La evaluación del aprendizaje se construyó en diálogo con los Estudios de la Infancia. Los círculos de conversación se han realizado utilizando tarjetas con dibujos y símbolos, grabados en videos, fotografías y notas. El análisis mostró que estrategias como sentarse en la silla, debatir lo que se representa en las imágenes y hablar espontáneamente, si pudieran provocar discursos importantes por parte de los niños y mostrar un aprendizaje de una naturaleza diferente.

Palabras clave: Metodología de evaluación. Educación por el cine. Círculos de conversación. Aprendizaje. Infancia.

\section{Introdução}

Este trabalho apresenta e discute uma metodologia de avaliação com o uso de imagens para aplicação em oficinas de cinema ou outros projetos pedagógicos com crianças. A metodologia vem sendo desenvolvida e testada em estudos do Grupo de 
Pesquisa em Educação e Mídia (GRUPEM), da Pontifícia Universidade Católica do Rio de Janeiro (PUC-Rio). O uso de cartões com imagens em pesquisas e oficinas realizadas pelo grupo tem facilitado o diálogo entre pesquisadores e crianças em entrevistas ou rodas de conversa. Vivendo em uma era de profusão de imagens, seu protagonismo torna-se inevitável ao universo da pesquisa científica, que pode se valer da intimidade que as crianças têm com a linguagem imagética. Por meio das imagens dos cartões, as crianças apoiaram suas falas para a construção de narrativas sobre o que vivenciaram nas oficinas e durante a pesquisa ou sobre o que pensavam sobre determinado tema.

A sustentação da investigação se deu com o auxílio de diferentes autores. Para a criação e aplicação das oficinas os principais referenciais foram Vega (2015), Bergala (2008) e Migliorin et al. (2016). As reflexões sobre pesquisas com crianças foram possíveis com a contribuição dos Estudos da Infância. E a escolha e criação da metodologia estão fundamentadas nos estudos de Moura e Lima (2014), Ostetto (2006), Warschauer (1993), Garcez, Duarte e Eisenberg (2011), Kaufmann (2013), Vianna (2003) e Malaguzzi (1999).

O estudo aqui apresentado é resultado da intersecção de pesquisas das autoras, que durante o Doutorado que realizam/realizaram em Ciências Humanas - Educação, na PUC-Rio, têm proposto um diálogo entre os Estudos da Infância, Cinema e Educação. A metodologia de avaliação com imagens foi testada após a Oficina de Cinema Somos Todos Humberto Mauro, realizada durante o ano de 2017, com crianças dos anos iniciais do ensino fundamental em uma escola municipal de Cataguases $-\mathrm{MG}^{3}$. A proposta era compreender o que as crianças participantes das oficinas pensavam e sentiam em relação aos filmes com os quais tiveram contato, à produção audiovisual e ao cinema e, também, saber de que forma significaram essa experiência no cotidiano escolar. Sem a pretensão de ineditismo, o artigo busca sistematizar a experiência de construção dessa metodologia de avaliação, visando sua utilização em outros espaços e contextos.

O artigo está organizado a partir da apresentação da Oficina de Cinema Somos Todos Humberto Mauro e da construção da metodologia de avaliação, seguindo uma trajetória que vai da elaboração dos cartões com imagens até sua aplicação junto às

\footnotetext{
${ }^{3}$ Todos os participantes e/ou seus responsáveis assinaram termo de consentimento para uso de imagens e participação na pesquisa.
} 
crianças. A reflexão sobre a experiência mostra que estratégias simples, como sentarse no chão para uma roda de conversa, debater sobre o que está representado em imagens e falar espontaneamente sobre o que vivenciaram, podem suscitar falas muito interessantes das crianças. Destaca-se, assim, a necessidade da escuta sensível das crianças pelo adulto, seja ele condutor da oficina, monitor, professor ou pesquisador. A avaliação evidencia que o processo educativo pelo e para o cinema ocorre nas sutilezas das relações entre sujeitos e imagens, revelando que as aprendizagens das crianças podem extrapolar o esperado.

\section{Apresentação da "Oficina de Cinema Somos Todos Humberto Mauro"}

- O nome eu não sei não, mas eu sei para o que serve! - A gente diz: "luz, câmera, ação" e o filme começa.

(Registros de pesquisa, 2017)

A oficina de cinema onde a metodologia com o uso de cartões foi testada, faz parte de uma experiência piloto de metodologia de pesquisa de doutorado, de uma das autoras deste artigo, realizada no Polo Audiovisual da Zona da Mata de Minas Gerais ${ }^{4}$, na cidade de Cataguases.

O Polo Audiovisual foi inaugurado em 2010 a partir de mobilizações e articulações estabelecidas entre empresas, governos municipal, estadual e federal, universidades, fundações, artistas e intelectuais. Desde então, promove oficinas, cursos e ações de intercâmbio no Brasil e exterior, voltados para a qualificação técnica e artística das pessoas da região, para que possam obter postos mais qualificados nas produções realizadas. Esta profissionalização de agentes locais, combinada com investimentos financeiros, atrai realizadores de todo o país e já resultou na produção de longas e curtas-metragens, ficção, documentários, animações, videoclipes musicais, produções para TV, internet e mídias móveis. Além destes, estão entre suas atividades festivais, fóruns e arenas de debate, em ambientes que favorecem o intercâmbio de experiências e a interlocução entre profissionais do audiovisual, estudantes, educadores e gestores, com participação de pessoas de diversas partes do Brasil e do exterior. $^{5}$

\footnotetext{
${ }^{4}$ Doravante denominado Polo Audiovisual.

${ }^{5}$ Informações obtidas no site do Polo Audiovisual.
} 
Desde que definiu seu objeto de estudo, a pesquisadora passou a se envolver fortemente nas atividades desenvolvidas pelo Polo Audiovisual. Paralelo a isso, aceitou um convite da Secretaria Municipal de Educação de Cataguases para ministrar cursos para professores sobre mídias e, em especial, sobre cinema e montou um cineclube em uma escola municipal. Tal escola foi escolhida, em acordo com o secretário municipal de educação, porque está entre as que possuem o maior número de crianças de camadas populares, além de estar situada em um bairro da periferia da cidade, com características de localidade rural. É uma escola pequena, que atende 104 crianças da Educação Infantil e do primeiro segmento do Ensino Fundamental. As crianças atendidas encontram-se em situação de vulnerabilidade social, em razão da violência e da ausência de oportunidades de acesso a atividades de lazer e de cultura. Assim, foi entendido como importante oportunizar às crianças o acesso a filmes que estão fora do circuito comercial, especialmente, mas não somente, as produções nacionais.

O cineclube promove exibições de filmes para alunos e professores, às vezes juntos, às vezes separados, acompanhados de pipoca e seguidas de discussões sempre muito instigantes. Foi inaugurado no dia 28 de junho de 2017, com a exibição do primeiro filme rodado no Polo Audiovisual, Meu Pé de Laranja Lima (BERNSTEIN, 2012), depois de uma articulação estabelecida entre a Secretaria Municipal de Educação e o Polo Audiovisual.

Além de exibições quinzenais abertas à comunidade, juntamente com os professores, o cineclube passou a oferecer uma oficina de cinema e fotografia para as crianças e sessões de exibição de curtas ligados aos planejamentos de ensino e de eventos promovidos pela escola. A iniciativa foi inspirada em Alicia Vega e em sua Oficina de Cinema para Crianças, criada em 1985, em Renca, Chile. Vega (2015) relata que, quando criou o projeto, não imaginava que ele poderia servir para torná-los diretores de filmes, atores, editores ou qualquer outra função relacionada ao ofício. Seus objetivos eram bem mais simples e o que desejava era que os niños pudessem usufruir de um espaço onde a arte, a emoção e a brincadeira andassem juntas. $E$ foi também com este desejo que as atividades foram desenvolvidas. O objetivo principal foi introduzir e desenvolver conceitos relacionados ao audiovisual e as mídias digitais e estimular o hábito de ver filmes, pensar e discutir sobre suas temáticas.

Bergala (2008, p. 59) fala de um momento decisivo: 
da infância e da adolescência, em que cada um encontra os filmes essenciais na constituição de sua relação com o cinema. Esses filmes, em número limitado, cada um de nós os carregará a seu modo pela vida afora como uma espécie de reservas indestrutível.

Por isso a necessidade de oportunizar às crianças diferentes opções de filmes que estão fora do circuito comercial. "Nada, em seguida, poderá substituir esta primeira emoção que marca todo verdadeiro encontro com o cinema" (BERGALA, 2008, p. 60).

Na perspectiva de Bergala (2008) e seguindo os trilhos percorridos por Vega (2015) buscou-se mostrar aos alunos que o fundamental é se dar conta de que podemos brincar com imagens e que o movimento delas foi sempre uma preocupação do ser humano.

A oficina foi dividida nas etapas Ver e Fazer. Na primeira, além da exibição dos filmes para toda a comunidade, falou-se sobre a importância de Cataguases para o cinema, do porquê de tantos filmes estarem sendo gravados na cidade, sobre Humberto Mauro ${ }^{6}$, além de serem apresentados conceitos básicos relacionados ao cinema e à fotografia.

A etapa Fazer teve início com realização de fotos realizadas na escola e no seu entorno. Em seguida as crianças realizaram filmes de um minuto cujos métodos foram inspirados e adaptados da cartilha Cadernos do Inventar: cinema, educação e direitos humanos de Migliorin et al. (2016). A partir das propostas contidas na publicação, crianças e professoras optaram por realizar o Minuto Lumière, Fotografias Narradas, Histórias dos Objetos, Molduras e Espelhos de Auto Retrato.

O caderno ainda possui muitas outras sugestões. As propostas escolhidas, segundo as professoras, foram as mais adequadas a faixa etária e escolaridade das crianças. Para executar as ações as crianças se dividiram e seis grupos: dois do quarto ano e quatro do quinto. Cada grupo do quinto ficou responsável por um tema e os do quarto por dois. O primeiro passo foi a escrita do roteiro, onde deveria constar local das gravações, datas, horários, nome dos entrevistados, o que e como seria filmado.

\footnotetext{
${ }^{6}$ Considerado pioneiro do cinema nacional, realizou em Cataguases seus primeiros filmes, na década de 1920, período posteriormente denominado Ciclo de Cinema de Cataguases.
} 
Figura 1 - Storyboards: Minuto Lumière/ Sons do Recreio e Fotografias Narradas/ Quando me tornei professora.

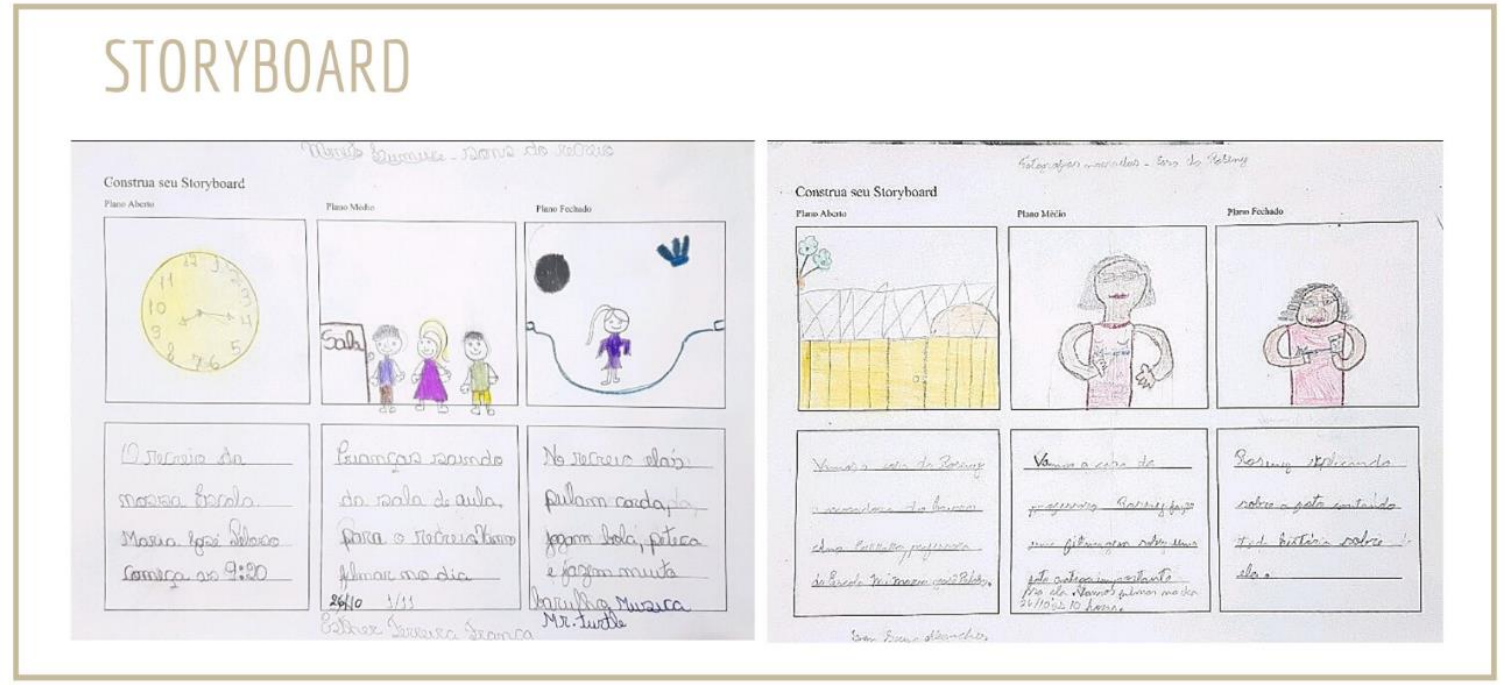

Fonte: Acervo da Oficina de Cinema Somos Todos Humberto Mauro, 2017.

Com o roteiro pronto as gravações foram agendas e realizadas. Com os grupos menores foi possível aprimorar as técnicas de filmagem e todos puderam participar porque as funções de diretor, produtor, câmera, áudio mudavam durante as gravações.

A edição dos filmes foi feita por apenas um componente de cada grupo, escolhido pelas próprias crianças. Para isso, foi usado o Windows Movie Maker, um software de montagem de vídeos para iniciantes que possibilita a criação, edição e o compartilhamento dos vídeos na internet de maneira simplificada. O tempo máximo para os vídeos foi de dois minutos. Depois de prontos foram gravados em DVD e publicados no blog Curtinhas $^{7}$, um espaço construído já há algum tempo, para reunir vídeos de um minuto criados por crianças, jovens e senhores e senhoras de Cataguases-MG.

A finalização do trabalho se deu com a mostrinha de cinema e exposição de fotografias, quando foi também aplicada a metodologia de avaliação com o uso de imagens sobre a qual propõem-se refletir. Antes, porém, é importante apresentar um breve relato do processo de elaboração dos cartões que foram utilizados na avaliação com as crianças participantes.

${ }^{7}$ Disponível em: https://curtinhascataguases.blogspot.com/. 


\section{Percurso de avaliação das oficinas: a construção dos cartões}

Os cartões com imagens começaram a ser pensados nos encontros do GRUPEM/PUC-Rio. Os investigadores do grupo, sob orientação da professora Rosalia Duarte, têm procurado desenvolver metodologias com o uso de imagens, para serem utilizadas, principalmente, em pesquisas com crianças e adolescentes. A intenção é que as imagens ajudem a conduzir entrevistas ou rodas de conversa e facilitem a construção de narrativas que tracem a trajetória empírica da pesquisa, na perspectiva do participante, e que se consiga identificar quais as aprendizagens das crianças, a partir da experiência com o cinema.

No caso de oficinas, as imagens podem dar respaldo às narrativas que contribuirão para a avaliação do processo, como um todo. Falar com o apoio de imagens pode ser uma interessante estratégia de participação ativa das crianças na pesquisa, sem que elas sintam que estão sendo arguidas ou testadas pelo pesquisador. Procura-se, nesta pesquisa, entender o que os participantes pensam e sentem em relação aos filmes, à produção audiovisual e ao cinema, e considera-se que o uso desta metodologia contribuiu para que fizessem isso de forma descontraída e lúdica.

Gaitán (2006) pontua que pesquisas com crianças devem levar em conta as particularidades dos contextos sociais, culturais, étnicos, geográficos e históricos. É preciso que se crie métodos ou se adote práticas que permitam analisar diferentes âmbitos que envolvem a infância, através de uma atitude de reconhecimento de diferentes "infâncias" - o que justifica a utilização do termo no plural. Nessa perspectiva, não se trata apenas de "dar a voz" às crianças, mas de se promover caminhos para que elas sejam ouvidas e compreendidas.

Historicamente, as crianças não têm feito integralmente parte das pesquisas das quais participam, pelo fato de pertencerem a "um grupo etário que não realiza pesquisa (científica e) tem, pois, que deixar a interpretação das suas vidas para outro grupo etário cujos interesses não estão potencialmente em consonância com os seus próprios interesses" (QVORTRUP, 1999, p. 05).

Após estabelecermos a compreensão de que precisávamos organizar tempos e espaços para que as crianças fossem verdadeiramente ouvidas, passamos a debater sobre a natureza das aprendizagens que elas poderiam ter construído ao longo da realização da oficina para que pudéssemos elaborar os cartões avaliativos. No que 
tange o desenvolvimento cognitivo das crianças, determinamos que a aprendizagem de conceitos técnicos relativos à linguagem do cinema possuiria o mesmo valor/peso das aprendizagens engendradas nas relações sociais vivenciadas. Com base nos estudos de Leontiev (1988), a oficina é pensada como forma de ampliação do repertório cultural das crianças, podendo contribuir no desenvolvimento de capacidades especificamente humanas.

Inicialmente, foi fundamental retomar os objetivos iniciais da oficina. Assim sendo, os primeiros cartões foram desenvolvidos correspondendo ao objetivo principal, de introduzir e desenvolver conceitos relacionados ao audiovisual e as mídias digitais. Nesses cartões, foram representados alguns elementos que remetem diretamente à experiência com o cinema.

Figura 2 - Cartões avaliativos sobre a linguagem do cinema.

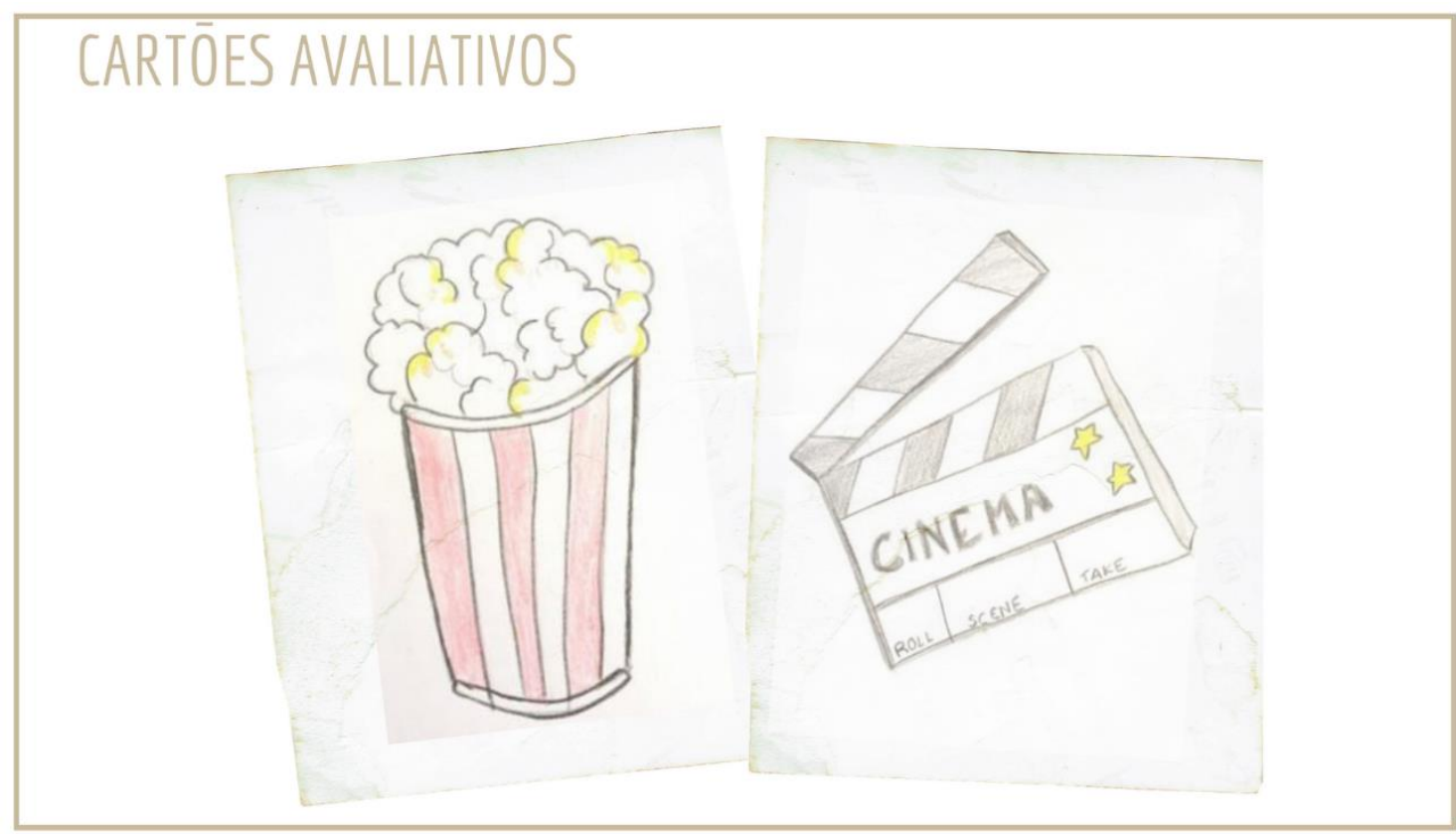

Fonte: Elaborado pelas autoras, 2017.

Os cartões foram confeccionados de forma colaborativa entre as pesquisadoras, desde a etapa de escolha de quais deveriam ser as figuras representadas, até a etapa prática, que envolveu: desenhar, colorir, digitalizar as imagens, imprimir, recortar e colar os cartões e plastificá-los, para que o material ficasse mais resistente e para que pudesse ser utilizado outras vezes em pesquisas futuras do grupo. 
Tinha-se, ainda, como objetivo da oficina de cinema, que os alunos construíssem outras aprendizagens na interação com o grupo e com o professor que a conduzia. Por isso, pensou-se, também, em cartões que colocassem em pauta as emoções vivenciadas, evidenciando, principalmente, situações de conflito entre o grupo que pudessem ter ocorrido durante o ano, estimulando que narrassem esses momentos e refletissem sobre eles. Para Bissoli (2014, p. 590) quando o adulto permite que a criança expresse aquilo que aprendeu, "cada tarefa adquire sentido e, pelo envolvimento emocional que permite, contribui para o desenvolvimento das diferentes capacidades da criança". Essas aprendizagens, de natureza mais subjetiva, são difíceis de serem mensuradas, mas quando levadas em consideração podem ser fundamentais para a realização não apenas de oficinas de cinema, mas também em outras atividades em grupo realizadas no cotidiano escolar, ou mesmo em espaços de educação não formal. Esses cartões tiveram como foco, por exemplo, situações em que alguma criança pudesse ter se sentido excluída do grupo ou possíveis discussões desrespeitosas em tom acalorado.

Figura 3 - Cartões avaliativos sobre aprendizagens subjetivas.

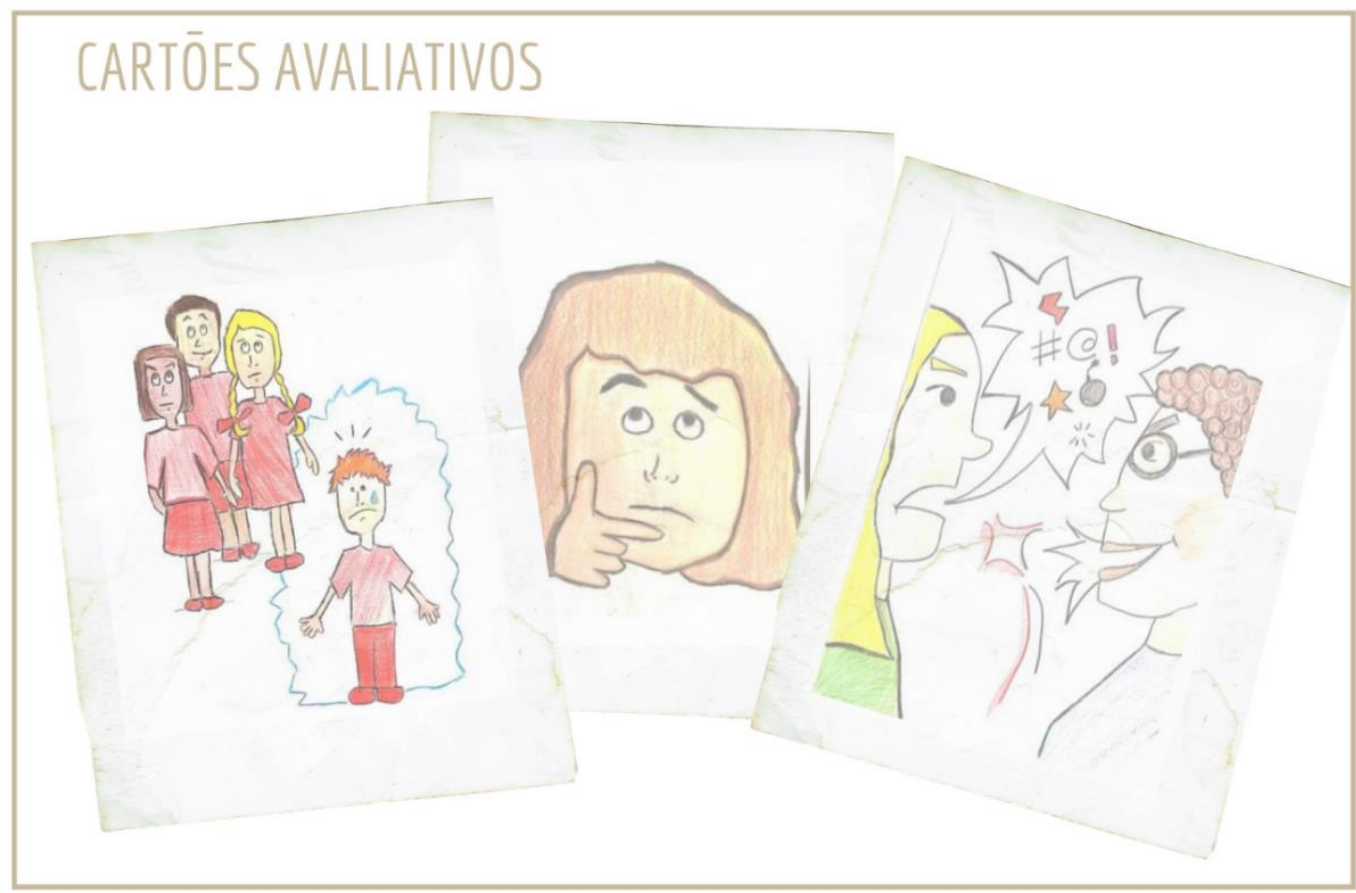

Fonte: Elaborado pelas autoras, 2017. 


\section{Percurso de avaliação das oficinas: a aplicação da metodologia}

A avaliação da participação na oficina de cinema foi realizada pelas próprias crianças. Assim, foram realizadas rodas de conversa, onde puderam debater sua participação individual e em grupo, tendo o apoio dos cartões. Como uma das pesquisadoras já havia conduzido as oficinas ao longo do ano e estabelecido um grande envolvimento com as crianças, decidiu-se que a avaliação não poderia ser realizada apenas por ela e que seria importante contar com opinião de alguém menos envolvido emocionalmente com o grupo. Dessa forma, a segunda pesquisadora esteve por dois dias na cidade de Cataguases e acompanhou à culminância do projeto, momento em que houve a exibição dos filmes produzidos pelas crianças ${ }^{8}$.

A chegada da segunda pesquisadora à escola foi intermediada pela professora da oficina (e pesquisadora), que fez uma apresentação breve, explicando às crianças que se tratava de uma atividade importante para a conclusão do trabalho e que poderiam ficar à vontade para falar tudo o que desejassem. Antes mesmo de entrarmos na sala de aula, as crianças se adiantaram em contar que papeis executaram durante as oficinas de cinema: "Eu fui o diretor!", "Eu fui o câmera!", "Eu a produtora!", "Eu editei!".

Optou-se por aplicar a metodologia dos cartões através da dinâmica de rodas de conversa, reconhecendo que a estratégia da roda não é inédita e que já foi amplamente discutida por outros autores (FREIRE, 1997; MOURA; LIMA, 2014; SCHIEFLER; SILVA, 2000). Moura e Lima (2014, p. 100) defendem que este formato metodológico pode ser utilizado como instrumento de pesquisa, tornando o ambiente favorável ao diálogo, onde "todos possam se sentir à vontade para partilhar e escutar, de modo que o falado, o conversado seja relevante para o grupo e suscite, inclusive, a atenção na escuta."

A roda de conversa é uma estratégia muito utilizada em práticas da educação infantil, sendo, muitas vezes, pensada na configuração do espaço das salas de aula,

\footnotetext{
${ }^{8}$ Esse segundo momento ocorreu com um evento no turno noturno, aberto à comunidade escolar. Além da exibição dos filmes, as crianças tiveram oportunidade de falar sobre a experiência de produção audiovisual. As professoras e pesquisadoras também fizeram uma fala à comunidade sobre a realização da Oficina e sobre essa pesquisa. Essa atividade também foi registrada e será avaliada em outras delimitações da pesquisa.
} 
com a disposição de um tapete e almofadas. Porém, a partir da transição para o ensino fundamental, quando passam comumente a ser configuradas em fileiras, as crianças de certa forma perdem esta oportunidade de conversar em roda. Assim, considera-se que a roda de conversa, na avaliação das oficinas, torna-se mais do que uma ferramenta metodológica de pesquisa, é uma possibilidade de encontro.

Tendo como inspiração a experiência das rodas de conversa na educação infantil, Ostetto (2006, p. 158) pontua que:

[...] mais do que fazer a roda e chamar para o encontro, por si só já é uma ação carregada de simbolismo, entra em jogo o exercício de uma atitude e um pensamento circulares. Pensar circularmente significaria não pensar em uma linha reta, na afirmação da verdade, da única voz, do conhecimento único. Significaria abrir-se ao diálogo, ao acolhimento da dúvida e da diversidade, à construção de múltiplos enredos afirmados no encontro das singularidades de crianças e adultos, de alunos e professores. Não uma técnica, procedimento metodológico, mas um modo de agir, de ser, de acolher.

Ficou sob responsabilidade das crianças a distribuição dos integrantes que participariam de cada uma, de três rodas de conversa. Foram 9 meninas e 10 meninos, que se distribuíram em grupos de 5, 6 e 8 . As conversas aconteceram em uma sala de aula da própria escola e tiveram a duração de aproximadamente 20 minutos cada uma. Ao entrarem na sala, as crianças estranharam o fato do mobiliário ter sido afastado e de terem que sentar no chão, se havia cadeiras para isso. Constatamos que, na escola, sentar-se em círculo e no chão não é um costume entre as turmas de quarto e quinto anos.

O círculo, a roda e a circunferência trazem consigo a simbologia da integração, do todo, do conjunto. A roda não tem início e nem fim, é uma possibilidade de todos estarem juntos, em equilíbrio. Para Warschauer (1993, p. 50), a roda é um momento privilegiado de troca entre os participantes, "sentar-se de forma que todos vejam o círculo, já é um convite a querer falar e ouvir. O respeito pela individualidade é a base de construção do grupo".

Roda e círculo evocam equilíbrio, totalidade, diferenças, interdependência. $\mathrm{Eu}, \mathrm{tu}$, ele, o conhecimento em relação, Lado a lado, possibilitado pelo desenho que não tem ângulos. Na forma circular, a imagem de um coletivo composto de individualidades que não desaparecem no contorno do grupo (OSTETTO, 2006, p. 155). 
Com todos sentados ao chão, os cartões foram dispostos no centro do círculo. Logo ao início explicamos como funcionaria a dinâmica da atividade. Todas as rodas de conversa foram registradas em vídeo e em anotações feitas pelas pesquisadoras. Optamos por vídeo-gravações, por considerarmos que proporcionam mais respaldo e fidelidade para a posterior análise dos dados. Garcez, Duarte e Eisenberg (2011, p. 260) salientam que a possibilidade de realizar registros e codificações minuciosos é um dos maiores méritos da vídeo-gravação, por proporcionar "maiores confiabilidade, fidedignidade e riqueza na produção e na análise de material empírico".

Mesmo tendo apoio na vídeo-gravação, fizemos anotações escritas durante todo período de avaliação. Com um bloquinho e caneta no bolso, sempre que as crianças diziam algo que pudesse gerar reflexões futuras, anotávamos frases curtas ou palavras-chave. De acordo com Ostetto (2008, p. 13),

[...] por meio do registro escrito travamos um diálogo com nossa prática, entremeamos perguntas, percebendo idas e vindas, buscando respostas que vão sendo elaboradas no encadeamento da escrita, na medida em que o vivido vai se tornando explícito e, portanto, passível de reflexão.

Ao início da dinâmica, as crianças mais desinibidas tomaram a frente, percebendo que havia resistência por parte de alguns colegas: "Tia, deixa que eu começo. Ele não gosta muito de falar". O silêncio que se fez na roda sinalizou que as crianças poderiam não estar totalmente à vontade para falar e que se poderia ter iniciado com alguma atividade de interação entre pesquisadoras e crianças. Em uma pesquisa, é importante que se reconheçam os percalços e obstáculos de desenvolvimento.

Vianna (2003) chama a atenção para o grau de influência que a presença do pesquisador pode causar e modificar o contexto e a situação pesquisada. Para essa pesquisa, prevíamos que isso pudesse ser potencializado pelo fato de os participantes serem crianças. Podemos observar, no entanto, que o uso dos cartões, contribuiu para que elas se sentissem mais confortáveis e desinibidas, "esquecendo" durante as conversas que uma das pesquisadoras não fazia parte de seu convívio.

Outro aspecto que preocupava era o fato de utilizarmos uma metodologia que ainda está sendo desenvolvida e testada, e que pode apresentar falhas. Por isso, 
optamos pela elaboração de estratégias que pudessem ser adaptadas durante sua realização. Logo ao início das rodas de conversa, percebemos que seria necessário adaptar algumas estratégias em uma próxima aplicação.

A ideia inicial era que as crianças, em círculo, sorteassem perguntas colocadas dentro de uma caixa e respondessem escolhendo um cartão com imagem que pudesse apoiar sua fala. As perguntas haviam sido elaboradas com base em aspectos da oficina e para respondê-las as crianças poderiam escolher qualquer cartão. No entanto, as crianças sorteavam uma pergunta do pote, escolhiam um cartão e falavam sobre o que estava sendo representado nele, estabelecendo relações interessantes com momentos específicos e vivências da oficina, mas que não diziam respeito necessariamente à pergunta que haviam sorteado. A pergunta acabava se perdendo na conversa. Concluímos, portanto, que a linguagem visual dos cartões se sobrepôs à linguagem escrita das perguntas. As imagens, dotadas de significado, permitiram às crianças enquanto leitoras uma gama de interpretações e significados, mas que não necessariamente respondiam às perguntas sorteadas.

Kaufmann (2013) alerta que em uma entrevista ou roda de conversa, a melhor pergunta é aquela elaborada durante a execução da atividade, quando o pesquisador deve encontrar o questionamento certo se baseando no que o entrevistado ou os participantes estão dizendo. Neste caso, a atividade proporcionará um momento de compartilhamento, bem mais próximo a uma "conversa" entre pessoas dispostas a dividir um conhecimento, uma ideia. A roda de conversa poderia, portanto, ter sido conduzida de forma mais livre, deixando que as falas fossem se desenvolvendo a partir das imagens e não somente a partir de perguntas preestabelecidas. Mas, de fato, de forma espontânea isso foi acontecendo.

Reações de estranheza como esta: "O que é um curta?" "Ué?!" "Mas já tá no nome já!" (Registros de pesquisa, 2017), demonstram que algumas perguntas pareciam demasiado óbvias para as crianças e, com isso, elas não precisavam necessariamente de apoio nas imagens dos cartões. Quando isso acontecia, a pergunta era rapidamente respondida e em seguida as crianças pediam se podiam assim mesmo escolher um cartão para comentar. No decorrer da atividade, a roda de conversa se tornou um momento de descontração e diálogo entre crianças e pesquisadoras e pudemos confirmar que as crianças, com a realização da oficina durante o ano, tiveram uma experiência cultural muito rica com o cinema. 
"Cinema não é só o lugar de assistir filmes, cinema também é fazer filmes".

"O que eu mais gostei foi aprender a fazer filme e também a aprender a ouvir, porque quando o diretor fala a gente tem que prestar atenção." (Registros de pesquisa, 2017).

Além de conceitos, técnicas e vivências de produção audiovisual, as crianças trouxeram à tona memórias muito significativas da oficina durante a avaliação. Ao escolher um cartão das emoções, por exemplo, relatavam que sentiram vontade de chorar assistindo a um filme específico ou que tiveram que pensar muito para encontrar alternativas de edição para seus próprios filmes. Essas falas demonstram que conseguiram fazer interessantes relações entre as imagens dos cartões com os momentos vivenciados e que o cinema Ihes possibilitou uma verdadeira experiência estética através do cinema.

Não raramente as crianças esqueciam o nome do filme assistido, mas lembravam, por exemplo, que no dia em que o filme foi exibido, elas comeram pipoca e que a sala escura estava muito confortável. Tem-se problematizado, a partir da realização das oficinas de cinema, os motivos pelos quais na escola, a dimensão estética tem sido considerada um interesse superficial, principalmente no que diz respeito aos cuidados com o bem-estar no ambiente e no espaço escolar como um todo. Vecchi $(2006$; 2017) sinaliza que o sentimento estético ocupa com facilidade diversos campos, é transversal em várias disciplinas, e não está somente ligado à arte. A autora defende a importância de que as crianças e todas as pessoas que trabalham na escola passem o dia em um ambiente onde as cores e os objetos sejam dispostos com cuidado e atenção. Para isso, todos os atores da escola, sejam eles crianças ou adultos, devem se sentir parte na formação e conservação de um ambiente agradável, contribuindo de diferentes formas para esse objetivo.

Pode-se afirmar que a oficina de cinema nas escolas pode ser uma forma interessante de contribuir com a formação estética das crianças. No que diz respeito aos processos de aprendizagem da criança, Vecchi (2006) acredita que a sensibilidade estética é responsável por estabelecer elos entre as coisas em si e é pela estética que as crianças fazem determinadas escolhas, como preferir um gesto a outro, selecionar determinado objeto, escolher uma cor ou um pensamento. "São escolhas em que se 
percebe harmonia, cuidado, prazer para mente e para os sentidos" (VECCHI, 2006, p. 17).

A despedida entre pesquisadoras e crianças se deu com a certeza de que a Oficina de Cinema Somos Todos Humberto Mauro deixou grandes marcas em cada uma. A metodologia de avaliação com o uso de imagens, embora ainda careça de aprimoramentos e atualizações, já indica ser um instrumento potente para a pesquisa com crianças, valorizando suas falas e suas narrativas em torno dos momentos vividos.

\section{Considerações finais}

É de suma importância a elaboração de metodologias de pesquisa específicas para o trabalho com crianças. O desenvolvimento de estratégias capazes de fazer com que as crianças se expressem livremente e que suas vozes sejam de fato ouvidas, possibilitam que as pesquisas não sejam uma interpretação única do adulto sobre o universo infantil. Esbarra-se, assim, em questões éticas. Como contar com a participação efetiva das crianças nas pesquisas, respeitando-as como sujeitos de direito? Ao se buscar responder a esse questionamento é que surgiu a inspiração de compor uma estratégia metodológica de avaliação para oficinas de produção audiovisual, podendo testá-la com as crianças participantes da Oficina de Cinema Somos Todos Humberto Mauro.

O envolvimento das pesquisadoras em todas as etapas de construção dessa metodologia possibilitou a percepção da importância do processo como um todo e não apenas do resultado. O foco não foi apenas a aplicabilidade da metodologia de avaliação. A dedicação se estabeleceu desde a ideia inicial, passando pela elaboração dos temas dos cartões, da criação dos desenhos, sempre discutindo nas reuniões do GRUPEM as possibilidades e expectativas.

Chegada a hora de testar a metodologia, foi necessário lidar com a "novidade" entre as crianças, o fato da presença de um pesquisador causar tanto estranhamento e causar alvoroço na rotina de uma escola teve que ser resolvido rapidamente para a boa aplicação da pesquisa. Porém, o fator chave para o sucesso dessa experiência, talvez tenha sido as pesquisadoras terem assumido que estavam trabalhando com uma metodologia ainda em desenvolvimento, que não está pronta, nem tem pretensão de ser um instrumento rígido e acabado. $O$ trabalho foi desenvolvido com um instrumento 
de avaliação flexível, que precisava ser testado junto às crianças. As reações e receptividade das crianças a essa metodologia são primordiais para seu amadurecimento e consolidação.

Foram encontradas dificuldades e falhas que não haviam sido previstas. Não se imaginava que as crianças dariam preferência às imagens dos cartões e que deixariam as perguntas condutoras do debate, de certa forma, de lado. Esse primeiro teste aponta para uma sobreposição da linguagem visual em relação à linguagem escrita. Isso talvez seja reflexo das vivências da vida contemporânea, do mundo de profusão de imagens em que todos estão inseridos. Deparar com esse aspecto e deixar com que as próprias crianças conduzissem a dinâmica da forma que se sentissem mais à vontade, possibilitou resultado satisfatório.

Com o apoio das imagens dos cartões, as crianças construíram inúmeras narrativas a respeito do que vivenciaram ao longo do ano. $E$, tratando especificamente das aprendizagens possibilitadas pelas oficinas de cinema, destaca-se a formação estética. Para a criança, a arte interessa como processo vivido, sentido e experienciado. Pôde-se conhecer as vivências das crianças com o cinema através do que elas próprias contaram. Nesse processo, foi oferecida escuta sensível, ouvindo-as com carinho e atenção.

Conforme já foi dito, a metodologia de avaliação com o uso de imagens não tem pretensão de ser um instrumento pronto e acabado, mas sim, ser uma lente de aumento às experiências vividas por crianças em oficinas de cinema ou de outro gênero. A intenção em compartilhá-la é de encorajar outras pessoas a contribuírem com essa discussão e com o aprimoramento de instrumentos metodológicos que tenham as crianças como foco, respeitando-as em sua integridade.

\section{Referências}

BERGALA, A. A hipótese-cinema: pequeno tratado de transmissão do cinema dentro e fora da escola. Rio de Janeiro: Booklink, 2008.

BISSOLI, M. de F. Desenvolvimento da personalidade da criança: o papel da educação infantil. Psicologia em estudo, v. 19, n. 4, p. 587-597, 2014. Disponível em: https://www.scielo.br/scielo.php?pid=S141373722014000400587\&script=sci_arttext\&tlng=pt. Acesso em: 20 out. 2019. 
FREIRE, M. Avaliação e planejamento: a prática em questão: instrumentos metodológicos II. São Paulo: Espaço Pedagógico, 1997.

GAITÁN, L. Sociología de la infância: análisis e intervención social. Madrid: Sintesis, 2006.

GARCEZ, A.; DUARTE, R.; EISENBERG, Z. Produção e análise de videogravações em pesquisas qualitativas. Educação e Pesquisa, São Paulo, v. 37, n. 2, p. 249-262, mai./ago. 2011.

KAUFMANN, J. A entrevista: um guia para a pesquisa de campo. Petrópolis: Vozes, 2013.

LEONTIEV, A. N. Uma contribuição à teoria do desenvolvimento da psique infantil. In: VIGOTSKII, L.; LURIA, A. R.; LEONTIEV, A. N. (org.). Linguagem, desenvolvimento e aprendizagem. 5. ed. São Paulo: Editora Ícone, 1988.

MALAGUZZI, L. História, ideias e filosofias básicas. In: EDWARDS, C.; GANDINI, L.; FORMAN, G. (org.). As cem linguagens da criança: a abordagem de Reggio Emilia na educação da primeira infância. Porto Alegre: Artmed, 1999.

Meu pé de laranja lima. Direção: Marcos Bernstein. Produção: Kátia Machado. Intérpretes: João Guilherme Ávila, José de Abreu, Caco Ciocler et al. Roteiro: Marcos Bernstein, Melanie Dimantas. [S. I]: Passaro Films; Globo Filmes, 2012. 97 min, color. MIGLIORIN, C. et al. Cadernos do inventar: cinema, educação e direitos humanos. Niterói: EDG, 2016.

MOURA, A. F.; LIMA, M. G. A reinvenção da roda de conversa: um instrumento metodológico possível. Temas em Educação, João Pessoa, v. 23, n. 1, p. 98-106, jan./jun. 2014. Disponível em:http://www.okara.ufpb.br/ojs/index.php/rteo/article/viewFile/18338/11399. Acesso em: 25 out. 2018.

OSTETTO, L. E. Educadores na roda de dança: formação, transformação. 2006. 250 f. Tese (Doutorado em Educação) - Universidade Estadual de Campinas. Campinas: Unicamp, 2006.

OSTETTO, L. E. Observação, registro, documentação: nomear e significar as experiências. In: OSTETTO, L. E. (org.) Educação infantil: saberes e fazeres da formação de professores. Campinas: Papirus, 2008.

POLO AUDIOVISUAL ZONA DA MATA DE MINAS GERAIS. Articulação, planejamento, realização, registro e difusão das produções que acontecem no âmbito do Polo 
Audiovisual. Minas Gerais, 2018. Disponível em: http://www.poloaudiovisual.org.br/. Acesso em: 13 maio 2018.

QVORTRUP, J. A infância na Europa: novo campo de pesquisa social. Minho: CEDIC, Instituto de estudos da criança, Universidade do Minho, 1999.

SCHIEFLER, A. R. K.; SILVA, S. F. da. Entre fadas, jacarés e pintores: a história de construção de um grupo: In: OSTETTO, L. E. (org.) Encontros e encantamentos na educação infantil. Campinas: Papirus, 2000.

TOLEDO, A. Curtinhas: apresenta iniciativa audiovisual onde crianças, jovens e senhores e senhoras de Cataguases/MG disponibilizam vídeos de aproximadamente 1 minuto realizados com celulares, 2018. Disponível em:

https://curtinhascataguases.blogspot.com/. Acesso em: 23 dez. 2018

VECCHI, V. Arte e criatividade em Reggio Emilia: explorando o papel e a potencialidade do ateliê na educação da primeira infância. São Paulo: Phorte Editora, 2017.

VECCHI, V. Estética y aprendizaje (Prólogo). In: HOYUELOS, A. (org.). La estética en el pensamiento y obra pedagógica de Loris Malaguzzi. Barcelona: Octaedro, 2006.

VEGA, A. Oficina de cinema para crianças. Rio de Janeiro/Porto Alegre: Programa de Alfabetização Audiovisual, 2015.

VIANNA, H. M. Pesquisa em educação: a observação. Brasília: Plano Editora, 2003.

WARSCHAUER, C. A roda e o registro: uma parceria entre professores, alunos e conhecimento. Rio de Janeiro: Paz e Terra, 1993.

Enviado em: 25/07/2019

Aprovado em: 19/05/2020 